\title{
Aktivitas Anti Oksidan Fikosianin Dari Spirulina Sp. Menggunakan Metode Transfer Elektron Dengan DPPH (1,1-difenil-2-pikrilhidrazil)
}

\author{
Ali Ridlo*, Sri Sedjati, dan Endang Supriyantini \\ Jurusan IImu Kelautan, Fakultas Perikanan dan IImu Kelautan, Universitas Diponegoro \\ JI. Prof. Soedarto, SH. Kampus UNDIP Tembalang, Semarang 50275 \\ E-mail :aliridlo26@gmail.com
}

\begin{abstract}
Abstrak
Mikroalga Spirulina sp. Memiliki kandungan fikosianin yang tinggi. Fikosianin berpotensi sebagai pewarna biru alami dan antioksidan.Tujuan dari penelitian ini adalah untuk menentukan aktivitas antioksidan fikosianin dari ekstrak Spirulina sp.dengan metode transfer elektron dengan DPPH (1,1-diphenyl picrilhydrazil). Spirulinasp. Diekstraksi dengan akuades dan buffer fosfat $\mathrm{pH}$ 7. Hasil penelitian menunjukkan bahwa kandungan fikosianin Spirulina sp. Yang diekstraksi dengan pelarut aquadest adalah $45,16 \pm 1,13 \mathrm{mg} / \mathrm{g} \mathrm{dw}$ dan $60,51 \pm 0,11 \mathrm{mg} / \mathrm{g}$ dw yang diekstraksi dengan pelarut buffer fosfat $\mathrm{pH}$ 7. Aktivitas antioksi dan fikosianin yang diekstraksi dengan aquades lebih tinggi (IC $50=110,80 \mathrm{ppm}$ ) dibandingkan fikosianin yang diekstraksi dengan buffer fosfat pH 7 (IC $50=186,76$ ppm). Keduanya termasuk dalam kategori antioksidan yang lemah.
\end{abstract}

Kata kunci : Spirulina sp., Fikosianin, Aktivitas Antioksidan, $\mathrm{IC}_{50}$

\begin{abstract}
Microalga Spirulina sp. has a high content of phycocyanin. Phycocyanin has potential as a natural blue colorant and antioxidants. The aim ofthis study wasdetermine the antioxidant activity of phycocianin extracted from Spirulina sp by electron transfer method with DPPH (1,1-diphenyl picrilhydrazil). Spirulina sp was extracted by aquadest and phosphat buffer $\mathrm{pH}$ 7. The results showed that content of phycocyanin of Spirulina sp. extracted with aquadest was $45.16 \pm 1.13 \mathrm{mg} / \mathrm{g} \mathrm{dw}$ and $60.51 \pm 0.11 \mathrm{mg} / \mathrm{g} \mathrm{dw}$ that extracted with phosphate buffer $\mathrm{pH}$ 7. Antioxidant activityof phycocianin extracted with aquadest was higher $\left(I C_{50}=110,80 \mathrm{ppm}\right) \quad$ than phycocianin extracted with phosphate buffer $\mathrm{pH} 7\left(\mathrm{IC} \mathrm{C}_{50}=186.76 \mathrm{ppm}\right)$. Both are included in the weak antioxidants category.
\end{abstract}

Keywords : Spirulina sp., Phycocyanin, Antioxidant Activity, IC 50

\section{PENDAHULUAN}

Spirulina sp. merupakan mikroorganisme autrotrof berwarna hijaukebiruan dengan sel berkolom membentuk filamen terpilin menyerupai spiral (helix), sehingga disebut alga biru-hijau berfilamen (cyanobacterium) (Richmond 1988 dalam Pamungkas, 2005).Bentuk Spirulina sp menyerupai benang, merupakan rangkaian sel yang berbentuk silindris dengan dinding sel berdiameter 1-12 $\mu \mathrm{m}$.Filamen Spirulina sp hidup berdiri sendiri dan dapat bergerak bebas (Richmond, 1988 dalam Pamungkas, 2005).

Spirulina, sp. mengandung pigmen biru fikosianinsekitar $20 \%$ berat keringnya. Kandungan fikosianin dalam Spirulina, sp. tergantung pada suplai nitrogen (Boussiba dan Richmond 1979; Arlyza, 2005). Fikosianin menghasilkan warna biru cerah (Sarada et al., 1999; Jespersen et al., 2005; Yan et al., 2011). Fikosianin merupakan 
pigmen yang berasosiasi dengan protein dan bersifat polar serta larut air, dapat diekstrak dengan menggunakan pelarut air atau buffer (Masojidek et al., 2004). Fikosianin telah digunakan sebagai pewarna alami makanan, kosmetika, dan obat-obatan.Fikosianinmerupakan protein kompleks yang mampu meningkatkan kekebalan tubuh, bersifat antikanker (Kozlenko dan Henson, 1998),dan antioksidan.

Antioksidan merupakan senyawa pemberi elektron (electron donor) yang mampu menginaktivasi berkembangnya reaksi oksidasi, dengan cara mencegah terbentuknya radikal bebas. Saat ini,antioksidan yang banyak digunakan dalam bahan pangan umumnya merupakan antioksidan sintetik seperti Propil Galat (PG), Tertiary Butylhydroquinone (TBHQ),Butylated Hydroxy Tolvene (BHT), dan Butylated Hydroxy Anisole (BHA). Penggunaan antioksidan sintetik sebagai bahan pangan tidak direkomendasikan oleh Departemen Kesehatan karena diduga dapat menyebabkan kanker (karsinogenik) (Barus, 2009). Hal ini mendasari untuk mencari senyawa antioksidan dari bahan alami. Antioksidan alami merupakan antioksidan yang diperoleh dari ekstrak bahan alami. Saat ini antioksidan alami umumnya berbahan dasar tumbuhan tingkat tinggi seperti daun pandan, daun suji, dan kunyit.

Aktivitas antioksidan dapat dideteksi menggunakan beberapa metode, salah satunya adalah metode transfer elektron menggunakan radikal DPPH $(1,1-$ difenil-2pikrilhidrazil). Uji DPPH adalah suatu metode yang efektif dan cepat untuk memperkirakan aktivitas antioksidan.Prinsip metode ini adalah mengukur daya peredaman ekstrak suatu bahan terhadap radikal bebas DPPH (Damayanti, 2004).

Sumber antioksidan alami yang banyak dikenal masyarakat umumnya berasal dari tumbuhan darat dan masih jarang yang mengetahui potensi biota air sebagai sumber senyawa antioksidan.Berdasarkan hal tersebut, perlu dilakukan penelitian tentang potensi aktivitas antioksidan fikosianin yang diekstrak dengan pelarut air dan buffer dari Spirulina sp. dengan metode transfer elektron DPPH.

Tujuan dilakukannya penelitian ini adalah mengetahui potensi antioksidan fikosianin yang diekstraksi darispirulina sp.

\section{MATERI DAN METODE}

Materi yang digunakan adalah mikroalga Spirulina spdalam bentuk kering (bubuk) yang diperoleh dari Balai Besar Pengembangan Budidaya Air Payau Jepara (BBPBAP). Pelarut yang digunakan adalah akuades dan larutan buffer fosfat yang dibuat dengan mencampurkan $\mathrm{KH}_{2} \mathrm{PO}_{4}$ dengan $\mathrm{NaOH}$.

Bahan kimia untuk uji aktivitas antioksidan dengan metode DPPH adalah 1, 1-diphenyl-2-picrylhydrazyl

(DPPH), aquades, metanol (p.a.), $\mathrm{NaOH}$ (p.a.), $\mathrm{KH}_{2} \mathrm{PO}_{4}$ (p.a.) dan kertas saring Whatman no. 42. Alat-alat yang digunakan meliputi neraca analitik, mortar dan penggerus, vortex, refrigerator, sentrifuse dan spektrofotometer UV-Vis.

Prosedur kerja untuk penelitian terdiri dari beberapa tahapan, yaitu persiapan pelarut buffer $\mathrm{KH}_{2} \mathrm{PO}_{4}-\mathrm{NaOH}$ pada $\mathrm{pH} 7$, ekstraksi pigmen fikosianin, analisis kadar pigmen fikosianin, pengukuran aktivitas penangkapan radikal bebas (antioksidan), dan pembuatan spektra UV-Visible.

Ekstraksi dilakukan dengan metoda coldmaceration dan freezingthawing.Sampel kering Spirulina spdigerusdengan mortar sampai halus, kemudian dimaserasi dalam aquades dengan perbandingan 1:100 (w/v) dan dihomogenasi dengan vortex selamal menit. Sampel dibekukan dalam freezer selama 12 jam, dilanjutkan proses thawing (pencairan sampel beku) selama 12 jam pada suhu kamar. Proses freezingthawingdilakukan 2 siklus. Filtrat disentrifugasi pada kecepatan $3000 \mathrm{rpm}$ selama 30 menit, kemudian disaring sehingga di peroleh ekstrak kasar fikosianin Spirulina sp. Filtrat fikosianin diukur absorbansinya dengn Spektrofotometer 
UV-VIS pada panjang gelombang $400-800$ $\mathrm{nm}$. Kadar fikosianin dihitung menurut Bennet dan Bogorad (1973) sebagai berikut:

$$
P C\left(m g \cdot m L^{-1}\right)=\frac{\left\{A_{620}-\left(0.7 \times A_{650}\right)\right\}}{7.38}
$$

Dimana :

PC : Kadar Phycocyanin

$A_{620}$ : Nilai absorbansi pada panjang gelombang ( $\lambda$ ) $620 \mathrm{~nm}$

$A_{650}$ : Nilai absorbansi pada panjang gelombang $(\lambda) 650 \mathrm{~nm}$

\section{Uji Aktivitas Antioksidan Ekstrak Fikosianin}

Satu $\mathrm{ml}$ larutan sampel dengan pelarut aquades dengan konsentrasi $(0,00$; $11,25 ; 22,50 ; 45,00 ; 90,00)$ ppm dan pelarut buffer fosfat dengan konsentrasi $(0,00$; $25,70 ; 51,40 ; 102,81 ; 205,61)$ ppm masingmasing dimasukkan ke dalam vial ditambah dengan $3 \mathrm{ml}$ reagen DPPH 0,1 $\mathrm{mM}$, Larutan diinkubasi pada suhu $370^{\circ} \mathrm{C}$ selama 30 menit. Pengukuran absorbansi dilakukan dengan menggunakan spektrofotometer pada panjang gelombang $517 \mathrm{~nm}$. Blanko dibuat dari $1 \mathrm{ml}$ DPPH tanpa ekstrak pada tiap seri konsentrasi ditambah dengan $3 \mathrm{ml}$ metanol. Persentase inhibisi dihitung dengan rumus :

$$
\% \text { Inhibisi }=\frac{A_{0}-A_{1}}{A_{0}} \times 100 \%
$$

Dimana :

Ao : absorbansi blanko

$A_{1}$ : absorbansi sampel

\section{HASIL DAN PEMBAHASAN}

Fikosianin merupakan pigmen alami dari Spirulina sp yang bersifat polar, sehingga dalam ekstraksinya digunakan pelarut yang bersifat polar.Ekstraksi Spirulina $\mathrm{sp}$ dengan pelarut buffer fosfat $\mathrm{pH} 7$ menghasilkan fikosianin lebih tinggi $(60,51 \pm 0,11 \mathrm{dw})$ dibandingkan dengan pelarut aquades $(45,16 \pm 1,13 \mathrm{dw})$ (Tabel 1). Hal ini diduga karena pelarut buffer fosfat dapat menarik pigmen lebih kuat dari dalam sel karena mampu mempertahankan kondisi asam maupun basa. Fungsi larutan penyangga adalah menstabilkan $\mathrm{pH}$, sehingga setelah proses ekstraksi, larutan fikosianin dalam kondisi stabil dan mampu memperkecil proses degradasi pigmen. Degradasi fikosianin akan terjadi jika derajat keasaman turun atau alkalinitas meningkat (stabil pH 4-9)

Kemurnian fikosianindapat diketahui berdasarkan rasio absorbansi pada $\lambda=620$ $\mathrm{nm}$ dan absorbansi pada $\lambda=280 \mathrm{~nm}$. Hasil penelitian menunjukkan bahwa fikosianin yang diekstraksi dengan pelarut buffer fosfat 1,74 \pm 0,03 lebih tinggi kemurniannya daripada fikosianin yang diekstraksi dengan akuades $1,61 \pm 0,05$. Kemurnian fikosianin pada penelitian ini sudah memenuhi syarat bahan pangan berkisar antara 1,61-1,74 (Hemlata et al., 2011).

Kandungan fikosianin pada Spirulina sp. berkisar 1-10\% berat kering (Sedjati et al., 2012). Sumber lain menyebutkan kandungan fikosianin dalam 10 gram Spirulina sp kering yaitu $1400 \mathrm{mg}$ atau sekitar $14 \%$ (Henrikson, 2000) dan bisa mencapai $20 \%$ dari total protein selnya (Thomas, 2010). Kandungan pigmen fikosianin yang tinggi tersebut, menjadi daya tarik bagi pengembangan dan dianggap memiliki pasar yang potensial dalam industry pangan dan kesehatan (Chrismandha et al., 2006).

Uji DPPH dilakukan untuk mengetahui nilai hambat ekstrak yang berpotensi sebagai antioksidan.IC50fikosianin diamati dengan melihat nilai persentase inhibisi absorbansi fikosianin pada tiap seri konsentrasi dibandingkan dengan larutan standar, kemudian dihitung dengan menggunakan analisis regresi linier sederhana. Hasil penelitian menunjukkan fikosianin yang diekstraksi dengan pelarut aquades memiliki $I_{50}$ sebesar 110,80 ppm, sedangkan dengan pelarut buffer fosfat adalah 186,76 ppm. (Tabel 2 dan 3).

Nilai $\mathrm{IC}_{50}$ berbanding terbalik dengan aktivitas antioksidan. Semakin rendah nilai $\mathrm{IC}_{50}$ maka semakin kuat aktivitas antioksidannya. Fikosianin dari ekstrak Spirulina sp. dengan pelarut aquades memiliki nilai $I_{50}$ sebesar 110,80 ppm, artinya bahwa konsentrasi 110,80 ppm dari 
Tabel 1. Kadar dan Kemurnian Fikosianin Spirulina sp

\begin{tabular}{ccccc}
\hline No. & Pelarut & $\begin{array}{c}\text { Fikosianin } \\
(\text { ppm) }\end{array}$ & $\begin{array}{c}\text { Fikosianin } \\
\text { (mg/g sampel) }\end{array}$ & $\begin{array}{c}\text { Kemurnian } \\
\text { (A620/A280) }\end{array}$ \\
\hline 1. & Aquades & $451,65 \pm 11,26$ & $45,16 \pm 1,13$ & $1,61 \pm 0,05$ \\
2. & Buffer $\mathrm{KH}_{2} \mathrm{PO}_{4-} \mathrm{NaOH}$ & $605,08 \pm 1,29$ & $60,51 \pm 0,11$ & $1,74 \pm 0,03$ \\
\hline
\end{tabular}

Tabel 2. Nilai $I_{50}$ Ekstrak Kasar Fikosianin dengan Pelarut Aquades

\begin{tabular}{ccc}
\hline Konsentrasi (ppm) & \% inhibisi & $\mathrm{IC}_{50}(\mathrm{ppm})$ \\
\hline 0,00 & 0,00 & \\
11,25 & 5,87 & \\
22,50 & 12,84 & 110,80 \\
45,00 & 23,38 & \\
90,00 & 39,57 & \\
\hline
\end{tabular}

Tabel 3.Nilai I $\mathrm{C}_{50}$ Ekstrak Kasar Fikosianin dengan Pelarut Buffer Fosfat pH 7

\begin{tabular}{ccc}
\hline Konsentrasi $(\mathrm{ppm})$ & \% inhibisi & $\mathrm{IC}_{50}(\mathrm{ppm})$ \\
\hline 0,00 & 0,00 & \\
25,70 & 6,48 & \\
51,40 & 14,04 & 186,76 \\
102,81 & 32,13 & \\
205,61 & 53,29 & \\
\hline
\end{tabular}

ekstrak akuades dapat menghambat 50\% aktivitas radikal bebas DPPH, sedangkan nilai $I_{50}$ ekstrak buffer adalah 186,76 ppm, berarti bahwa konsentrasi 186,76 ppm ekstrak buffer fosfat dapat menghambat $50 \%$ aktivitas radikal bebas DPPH.

Suatu senyawa dikatakan memiliki aktivitas antioksidan apabila senyawa tersebut mampu mendonorkan atom hidrogennya pada radikal bebas DPPH yang ditandai dengan terjadinya perubahan warna ungu menjadi kuning pucat (Molyneux, 2004). DPPH memiliki serapan yang kuat pada panjang gelombang $517 \mathrm{~nm}$ dalam bentuk teroksidasi (Masuda, 1999). Beberapa komponen Spirulina sp. yang diduga memiliki aktivitas antioksidan adalah senyawa fenolat, karotenoid, pigmen fikobiliprotein, klorofil, dan turunan klorofil (Estrada et al., 2001). Fikosianin (fikobiliprotein) adalah antioksidan alami atau primer dari kelompok phyłochemical, (Hamid et al., 2010).

Sesuai klasifikasi nilai $I_{50}$, ekstrak aquades fikosianin memiliki potensi antioksidan dengan kategori sedang karena mempunyai nilai IC50antara 101-150 ppm, sedangkan ekstrak fikosianin dengan buffer fosfat termasuk kategori lemah (antara 150 - 200 ppm)(Mardawati et al.,2008).Perbedaan potensi antioksidan ini diduga karena adanya senyawa kelompok lain di luar fikosianin yang ikut terekstrak dan juga memiliki kemampuan mereduksi radikal bebas DPPH.

Aktivitas antioksidan dari ekstrak Spirulina sp tergolong lemah, diduga karena merupakan ekstrak kasar,dimana dalam ekstrak ini belum murni senyawa antioksidan. Hal ini sesuai dengan Wikanta et al. (2005), yang menyatakan bahwa rendahnya aktivitas antioksidan dapat 
dikarenakan adanya zat pengotor yang terdapat dalam ekstrak. Selain itu Spirulina yang diekstraksi berupa serbuk kering. Proses pengeringan sangat berpengaruh atau merusak senyawa antioksidan. Sampel segar akan mempunyai aktivitas antioksidan yang lebih baik daripada sampel kering (Damar et al., 2014).

\section{KESIMPULAN}

Ekstrak fikosianin Spirulina sp berpotensi sebagai antioksidan alami. Penggunaan pelarut yang berbeda memberikan hasil aktivitas antioksidan yang berbeda pula. Pelarut buffer fosfat menghasilkan ekstrak fikosianin yang lebih banyak dan lebih murni dibanding akuades, tetapi aktivitas antioksidan ekstrak akuades lebih kuat daripada pelarutbuffer.

\section{UCAPAN TERIMA KASIH}

Penulis mengucapkan terima kasih kepada reviewer dan semua pihak yang telah membantu dalam menyelesaikan penulisan karya ilmiah ini.

\section{DAFTAR PUSTAKA}

Arylza, I.S. 2005.Phycocyanin dari Mikroalga Bernilai Ekonomis Tinggi sebagai Produk Industri.Oseana.XXX(3): 27-36.

Barus, P. 2009.Pemanfaatan Bahan Pengawet dan Antioksidan Alami pada Industri Bahan Makanan. Universitas Sumatra Utara, Medan.

Bennett, A. and L. Bogorad. 1973. Complementary Chromatic Adaptation in a Filamentous BlveGreen Alga. J. Cell. Biol. 58: 419-435.

Boussiba, S. and Richmond, A. 1979.Isolation and Purification of Fikosianin from The Blue Green Alga Spirulina platensis. Arch. Microbiol., 120: 155-159.

Chrismandha, T., Panggabean L.M., dan Mardiati, Y. 2006.Pengaruh Konsentrasi Nitrogen dan Fosfor terhadap Pertumbuhan, Kandungan Protein, Karbohidrat, dan Fikosianin pada Kultur
Spirulina fusiformis. Berita Biologi 8(3) : 163-169.

Damar, A.R., M.R.J. Runtuwene dan D. Silvia.2014. Kandungan Flavonoid dan Aktivitas Antioksidan Total Ekstrak Etanol Daun Kayu Kapur (Melanolepsis multiglandulosa Reinch). Jurnal Ilmiah Farmasi FMIPA UNSRAT, Manado. Vol.3(4): 11-21.

Damayanti, E. 2004.Mempelajari Aktivitas Antioksidan dan Antibakteri dari Ekstrak Campuran Rempah Minuman Cinnaale.(Skripsi). Fakultas Teknologi Pertanian, Institut Pertanian Bogor, Bogor. $52 \mathrm{p}$.

Estrada, J,E.P., P.B. Bescos and A.M. V. Fresno. 2001. Anti Oxidant Activity of Different Fractions of Spirulina platensisProtean Extract. II Farmaco 56: 497-500.

Hamid, A.A., O.O Aiyelaagbe, L.A. Usman, O.M. Ameen, dan A. Lawal. 2010. Antioxidant : its Medidal and Pharmacological Applications. African Journal of Pure and Applied Chemistry vol.4(8):142-151

Hemlata, G. Pandey, F. Bano. \& T. Fatma. 2011 . Studies of Anabaena sp. NCCU-9 with special reference to phycocyanin. J. Algae Biomass UtIn. 2(1): 30-51.

Henrikson, R. 2000.Earth Food Spirulina.Essential Fatty Acids and Phytonutrients.Ronore Enterprises, Inc. California.

Jespersen, L., L.D. Stremdahl, K. Olsen, and L.H.Skibsted. 2005. Heat and Light Stability of Three Natural Blue Colorant for Use in Confectionery and Beverages. Europ. Food Res. Technol. 220(3-4): 261-266.

Kozlenko, R, dan Henson, RH. 1998. Spirulina: Effects on the AIDS Virus, Cancer and the Immune System. Spirulina Health Library.www. Spirulina.com. (1 Nopember 2000).

Mardawati, E., Fitry, F., dan Herlina, M. 2008.Kajian Aktivitas Antioksidan Ekstrak Kulit Manggis (Garcinia mangostana L) dalam Rangka Pemanfaatan Limbah Kulit Manggis di Kecamatan Puspahiang Kabupaten Tasikmalaya. Fakultas Teknologi Industri. Universitas Padjadjaran, Bandung.

Masojidek, J., M. Koblizek, and G. Torzillo. 2004. Photosynthesis in Microalgae in: 
A. Richmond (Ed). Handbook of Microalgal Culture: Biotechnology and Applied Phycology. Blakwell Science Ltd., lowa. p.20-39.

Masuda, T. 1999. Evaluation of the Antioxidant Activity of Environmental Plants: Activity of the Extract from Sheashore Plants. J. Agronomy Food Chemistry. 47: 1749-1754.

Molyneux, P. 2004. The Use of Stable Free Radical Diphenylpicrylhydrazyl (DPPH) for Estimating Antioxidant. Songklanakarin J. Sci. Technol. $26(2): 212$.

Pamungkas, A. 2005. Sistem Taksonomi hewan dan tumbuhan. ANDI, Bandung.

Sarada, R., M.G. Pillai, dan G.A. Ravishankar. 1999. Phycocyanin from Spirulina sp.: Influence of Processing of Biomass on Phycocyanin Yield, Analysis of Efficiency of Extraction Methods and Stability Studies on Phycocyanin. J. Proc. Biochem. 34:795-801.
Sedjati, S., E. Yudiati dan Suryono.2012. Profil Pigmen Polar dan Non Polar Mikroalga Laut Spirulina sp dan Potensinya sebaagai Pewarna Alami. Jurnal IImu Kelautan., Vol. 17 (3): $176-181$.

Thomas, S.S. 2010.The Role of Parry Organic Spirulina in Health Management. India: Parry Nutraceuticals, Division of EID Parry (India) Ltd.

Wikanta, T., Januar H.D. dan Nursed, M. 2005. Uji Aktivitas Antioksidan, Toksisitas dan Sitotoksisitas Ekstrak Alga Merah Rhodymenia palmate. Jurnal Penelitian Perikanan Indonesia Vol. 11 (4): 12-25.

Yan, S., Zhu LP, Su HN, Zhang $X Y$, Chen $X L$, Zhou BC, and Zhang YZ. 2011. Singlestep Chromatography for Simultaneous Purification of C-Phycocyanin and Allophycocyanin with high Purity and Recovery from Spirulina (Arthrospira) platensis. J. Appl. Phycol. 23: 1-6. 